\title{
METODE ESTIMASI DAN PENGENDALIAN STATUS SISTEM JARINGAN DENGAN KERUGIAN PACKET
}

\author{
Pohny \\ Teknik Informatika, Fakultas Ilmu Komputer dan Teknologi Informasi, Universitas Mulawarman \\ Jl. Barong Tongkok Kampus Gunung Kelua, Samarinda, 75121 \\ E-mail : pohny28@gmail.com
}

\begin{abstract}
ABSTRAK
Pengenalan jaringan membawa banyak keuntungan, seperti pengurangan kabel, biaya yang lebih rendah dalam pemeliharaan, peningkatan kelincahan sistem, kemudahan berbagi informasi. Adapun metode yang digunakan adalah Linear Quadratic Gaussian Control dimana estimasi optimal dan kontrol optimal (LQG) untuk sistem seperti UDP tanpa observasi hilang. Untuk fokus pada sifat dampak sinyal pengakuan, peneliti menganggap sistem seperti UDP observasi tidak hilang. Hal ini menunjukkan bahwa estimator optimal terdiri dari eksponensial. Dengan meningkatnya syarat, tidak ada persamaan Riccati untuk menganalisis estimasi error kovarians, dan perhitungannya membutuhkan peningkatan waktu dan memori komputer secara eksponensial, estimator optimal untuk sistem seperti UDP diturunkan.Dengan kemajuan pesat dalam ilmu komputer, komunikasi dan kontrol teknik,titik-to-point arsitektur komunikasi tradisional untuk sistem kontrol, yang masing-masing komponen terhubung melalui kabel,tidak dapat memenuhi persyaratan industri modern, seperti modularitas, diagnostik terpadu, instalasi mudah dan pemeliharaan, dan kontrol di distribusikan. Mengatasi masalah ini menimbulkan sistem kontrol jaringan (NCSS), di mana komponen terhubung melalui jaringan. Pengenalan jaringan membawa banyak keuntungan, seperti pengurangan kabel, biaya yang lebih rendah dalam pemeliharaan, peningkatan kelincahan sistem, kemudahan berbagi informasi. Manfaat tersebut telah memberikan dorongan besar untuk luas aplikasi dari NCSS di berbagai bidang, seperti industri kendaraan, kontrol proses engineering, teleoperation, sistem tenaga, dan transportasi sistem. Namun pengenalan jaringan juga menyebabkan beberapa kendala network induced, seperti kemacetan saluran,delay transmisi, kerugian paket dan gangguan, jam asynchronization antara node lokal dan remote, data yang kuantisasi, persaingan beberapa node jaringan mengakses.
\end{abstract}

Kata Kunci: Estimasi,Jaringan,Kerugian paket, Sistem kontrol jaringan.

\section{PENDAHULUAN}

Untuk subjek jaringan untuk kerugian paket, dua protokol transportasi umum dikerahkan, yaitu, pengguna datagram protocol (UDP) dan protokol kontrol transmisi (TCP). Perbedaan utama antara kedua protokol terletak pada keberadaan mekanisme pengakuan. Dalam NCS dengan protokol TCP, ada pengakuan (ACK) dikirim dari aktuator untuk menginformasikan estimator apakah actuator telah berhasil menerima paket kontrol atau tidak. Sistem seperti ini biasanya disebut sebagai sistem TCP, NCS dengan protokol UDP yaitu, di mana ada adalah tidak ada ACK tersedia untuk estimator, disebut sebagai sistem UDP. Untuk sistem TCP mekanisme ACK memfasilitasi analisis teoritis, tapi dilaporkan bahwa untuk NCSS melalui jaringan tidak dapat diandalkan, tunduk pada jaringan jitter dan delay transmisi, sulit, kadang-kadang tidak mungkin, untuk mengirim ACK dalam waktu (Tanpa penundaan dan kerugian) untuk melaksanakan skema TCP. Untuk UDP sistem, dengan harga degradasi pertunjukan kontrol, implementasi protokol transport adalah disederhanakan dan konsumsi energi tambahan untuk ACK transmisi sinyal dihindari, menjadikannya pilihan lebih untuk realtime NCSS. Kecuali untuk kedua jenis arsitektur komunikasi, lain praktis model untuk NCSS adalah satu dengan ACK secara acak hilang, biasanya dikenal sebagai quasi-TCP sistem. Pada NCSs di hadapan kerugian paket telah membahas banyak bidang, misalnya, estimasi optimal,filtering, kontrol yang kuat, kontrol umpan balik, acara-dipicu kontrol, stabilisasi dan sebagainya dengan solusi optimal dan suboptimal ke estimasi dan kuadrat Gaussian (LQG) kontrol linear masalah bagi NCSS tanpa ACK atau dengan ACK hilang acak.

Telah diketahui di [2] bahwa estimasi optimal yang di inginkan $\mathrm{x}_{\mathrm{k} \mid \mathrm{k}}$ diberikan oleh $\mathrm{E}\left[\mathrm{x}_{\mathrm{k}} \mid \mathrm{I}_{\mathrm{k}}\right]$. Lalu beri tanda $\mathrm{X}_{\mathrm{k}+1} \mid \mathrm{k}, \mathrm{E}\left[\mathrm{x}_{\mathrm{k}+1} \mid \mathrm{I}_{\mathrm{k}}\right]$ sebagai prediksi status. Menyatakan $\mathrm{P}_{\mathrm{k} \mid \mathrm{k}}$ dan $\mathrm{P}_{\mathrm{k}}+1_{\mid k}$ sebagai estimasi dan prediksi error kovariansi. Misalkan $\mathrm{p}\left(\mathrm{x}_{\mathrm{k}} \mid \mathrm{I}_{\mathrm{k}}\right)$ dan $\mathrm{p}\left(\mathrm{x}_{\mathrm{k}}+1 \mid \mathrm{I}_{\mathrm{k}}\right)$ berlaku untuk fungsi kepadatan probabilitas (pdf) $\mathrm{x}_{\mathrm{k}}$ dan $\mathrm{x}_{\mathrm{k}}+1$ yang dikondisikan pada $\mathrm{I}_{\mathrm{k}}$. Kami pertama kali menurunkan fungsi kepadatan probabilitas (pdf) dari $\mathrm{x}_{\mathrm{k}}$, yaitu,p $\left(\mathrm{x}_{\mathrm{k}} \mid \mathrm{I}_{\mathrm{k}-1}\right)$ dan $\mathrm{p}\left(\mathrm{x}_{\mathrm{k}} \mid \mathrm{I}_{\mathrm{k}}\right)$, kemudian hitung perkiraan optimal.

Untuk sistem TCP mekanisme ACK memfasilitasi analisis teoritis, tapi dilaporkan bahwa untuk NCSS melalui jaringan tidak dapat diandalkan, tunduk pada jaringan jitter dan delay transmisi, sulit, kadang-kadang 
tidak mungkin, untuk mengirim ACK dalam waktu (Tanpa penundaan dan kerugian) untuk melaksanakan skema TCP. Untuk UDP sistem, dengan harga degradasi pertunjukan kontrol, implementasi protokol transport adalah disederhanakan dan konsumsi energi tambahan untuk ACK transmisi sinyal dihindari, menjadikannya pilihan lebih untuk real-time NCSS. Kecuali untuk kedua jenis arsitektur komunikasi, lain praktis model untuk NCSS adalah satu dengan ACK secara acak hilang, biasanya dikenal sebagai quasi-TCP sistem,

Pada NCSS di hadapan kerugian paket telah membahas banyak bidang, misalnya, estimasi optimal,filtering, kontrol yang kuat, kontrol umpan balik, acara-dipicu kontrol, stabilisasi dan sebagainya dengan solusi optimal dan suboptimal ke estimasi dan kuadrat Gaussian (LQG) kontrol linear masalah bagi NCSS tanpa ACK atau dengan ACK hilang acak.

\section{RUANG LINGKUP PENELITIAN}

Dalam penelitian ini permasalahan mencakup:

Status sistem dan perkiraannya. $\mathrm{X}^{(\mathrm{i})}{ }_{\mathrm{k}}$ adalah komponen ith dari keadaan sistem sebenarnya. " ${ }^{(i)}{ }_{k}$ : TCP" dan "X (i) ${ }_{\mathrm{k}}$ : UDP" adalah estimasi optimal $\mathrm{x}{ }_{\mathrm{k}}^{(\mathrm{i})}$ untuk sistem seperti TCP dan UDP, Sistem menyatakan dan perkiraannya. Sk|k dan $\mathrm{Pk} \mid \mathrm{k}$ adalah kovarian kesalahan estimasi untuk sistem seperti TCP dan UDP, waktu dari estimasi untuk sistem TCP, waktu dari estimasi untuk sistem UDP, menemukan kovarian kesalahan yang di harapkan,kotak input terbatas,masukan tak terbatas,kovarian kesalahan,masukan tak terbatas, urutan kovarian,kovarian kesalahan,keadaan sistem dan perkiraan kesalahan,kesalahan kuadrat rata-rata,inputan batasan,masukan yang tidak di izinkan,

1. Untuk subjek jaringan kerugian paket, dua protokol transportasi umum yaitu pengguna datagram protocol (UDP) dan protokol kontrol transmisi (TCP).

2. Dalam NCS dengan protokol TCP, ada pengakuan (ACK) dikirim dari aktuator untuk menginformasikan estimator apakah actuator telah berhasil menerima paket kontrol atau tidak.

3. NCS dengan protokol UDP, yaitu, di mana ada adalah tidak ada ACK tersedia untuk estimator disebut sebagai sistem UDP.

4. Untuk sistem TCP-seperti mekanisme ACK memfasilitasi analisis teoritis, tapi dilaporkan bahwa untuk NCSS melalui jaringan tidak dapat diandalkan, tunduk pada jaringan jitter dan delay transmisi,sulit,kadang-kadang tidak mungkin, untuk mengirim ACK dalam waktu (Tanpa penundaan dan kerugian) untuk melaksanakan skema TCP.

5. Untuk UDP sistem, dengan harga degradasi pertunjukan kontrol, implementasi protokol transport adalah disederhanakan dan konsumsi energi tambahan untuk ACK transmisi sinyal dihindari, menjadikannya pilihan lebih untuk real-time NCSS.

\section{BAHAN DAN METODE}

\subsection{Metode estimasi optimal}

Bagaimana pada NCSs di hadapan kerugian paket estimasi optimal,filtering, kontrol yang kuat, kontrol umpan balik,stabilisasi dengan solusi optimal dan suboptimal ke estimasi dan kuadrat Gaussian (LQG) kontrol linear masalah bagi NCSS tanpa ACK atau dengan ACK hilang acak.

\subsection{Sistem ACK}

Untuk kesederhanaan, peneliti menggunakan "kasus S/E" untuk menunjukkan kasus bahwa paket kerugian terjadi pada saluran sensor-ke-estimator (S/E), dan "kasus C/A (ACK)" untuk menunjukkan kasus yang mengendalikan paket dijatuhkan dengan ACK, dan "kasus $\mathrm{S} / \mathrm{E}+\mathrm{C} / \mathrm{A}$ (ACK)" untuk menunjukkan keduanya. Gagasan serupa berlaku untuk tidak ada pengakuan (NACK), dan terkait skenario dapat didefinisikan di jalan yang sama.

Sistem yang dijelaskan dengan ACK dilambangkan dengan SN, dan yang satu dengan ACK dilambangkan dengan SA. Peneliti fokus pada estimasi optimal dan masalah kontrol untuk kasus C/A (NACK). Jadi peneliti asumsikan saluran S/E bebas dari kerugian packet. Untuk sistem, peneliti membuat asumsi sebagai berikut:

\subsection{Diagram alir}

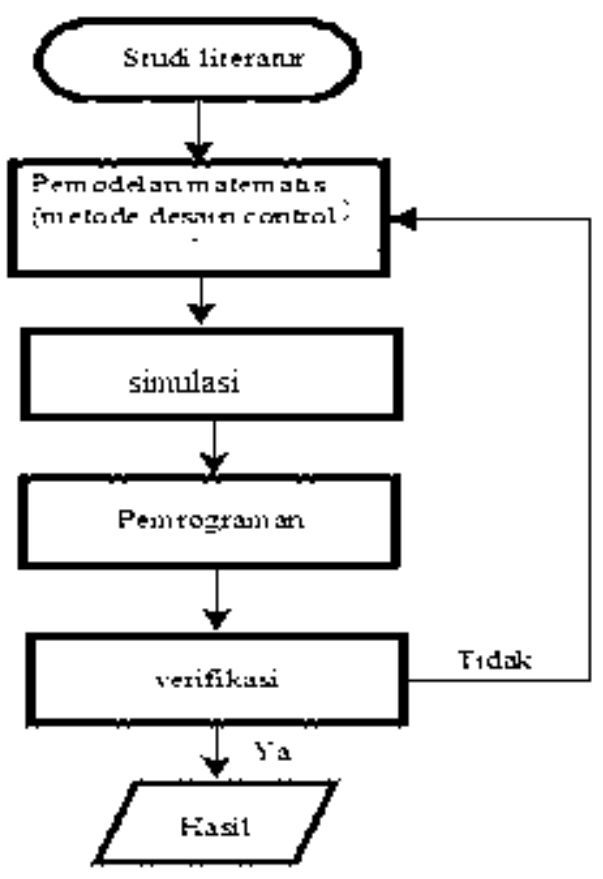

Gambar 1. Diagram Alir

Adapun yang di bahas dalam penelitian ini adalah sebagai berikut,

1. Pengenalan jaringan membawa banyak keuntungan, seperti pengurangan kabel, biaya 
yang lebih rendah dalam pemeliharaan, peningkatan kelincahan sistem, kemudahan berbagi informasi.

2. Pengenalan jaringan juga menyebabkan beberapa kendala network induced, seperti kemacetan saluran,delay transmisi, kerugian paket dan gangguan, jam asynchronization antara node lokal dan remote, data yang kuantisasi, persaingan beberapa node jaringan mengakses.

\section{RANCANGAN SISTEM}

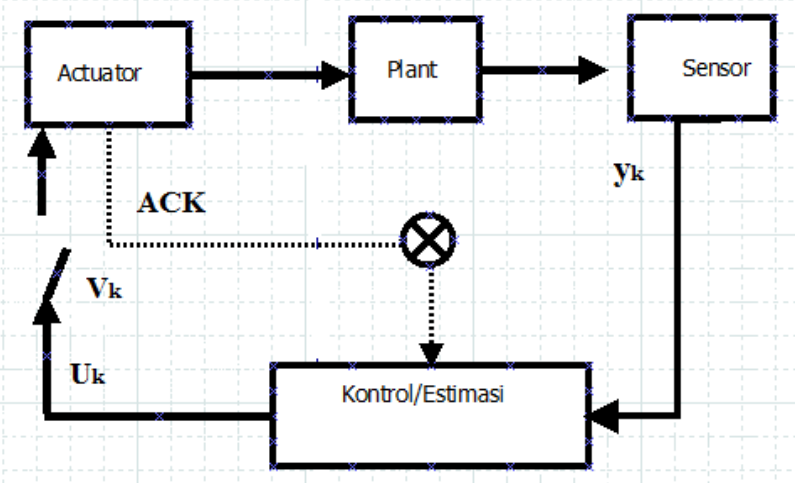

Gambar 2. NCSS dengan packet loss di C/A channel tanpa pengakuan. Simbol menunjukkan bahwa tidak ada pengakuan dari aktuator untuk estimator

bahwa tidak ada pengakuan dari aktuator terhadap estimator dimana $\mathrm{xk} \in \mathrm{R}_{\mathrm{n}}$ adalah keadaan sistem, uk $\in$ $\mathrm{Rq}$ masukan kontrol, dan $\mathrm{yk} \in \mathrm{R}^{\mathrm{p}}$ pengamatan. $\omega_{\mathrm{k}}$ dan $v_{\mathrm{k}}$ adalah nol berarti suara gaussian dengan kovarians $\mathrm{Q} \geq 0$ dan $\mathrm{R}>0$, masing-masing. $v_{\mathrm{k}}$. Urutan acak Bernoulli dengan mean $v$ untuk menggambarkan packet loss pada kanal kontrol ke aktuator (C/A).

Artinya, $v_{\mathrm{k}}=1$ menunjukkan bahwa paket kontrol $\mathrm{u}_{\mathrm{k}}$ telah berhasil dikirim ke aktuator, jika tidak $v_{\mathrm{k}}=0$. Kondisi awal $\mathrm{x}_{0}$ diasumsikan gaussian dengan mean ${ }^{-} \mathrm{x}_{0}$ dan kovarians $\mathrm{P}_{0}$.

Selain itu, $\mathrm{x}_{0}, v_{\mathrm{k}}, \omega_{\mathrm{k}}$, dan $v_{\mathrm{k}}$ saling independen. A, B, C, $\mathrm{Q}$, dan $\mathrm{R}$ adalah matriks dengan dimensi yang kompatibel.

Untuk kesederhanaan, peneliti menggunakan "kasus S/E" untuk menunjukkan kasus bahwa paket kerugian terjadi pada saluran sensor-ke-estimator $(\mathrm{S} / \mathrm{E})$, dan "kasus C/A (ACK)" untuk menunjukkan kasus yang mengendalikan paket dijatuhkan dengan ACK, dan "kasus $\mathrm{S} / \mathrm{E}+\mathrm{C} / \mathrm{A}$ (ACK)" untuk menunjukkan keduanya. Gagasan serupa berlaku untuk tidak ada pengakuan (NACK), dan terkait skenario dapat didefinisikan di jalan yang sama.

Sistem yang dijelaskan dengan ACK dilambangkan dengan SN, dan yang satu dengan ACK dilambangkan dengan SA. Peneliti fokus pada estimasi optimal dan masalah kontrol untuk kasus C/A (NACK). Jadi peneliti asumsikan saluran S/E bebas dari kerugian packet. Untuk sistem, peneliti membuat asumsi sebagai berikut:

\section{IMPLEMENTASI}

\subsection{Pengaturan Sistem}

Dalam peneliti, pembahasan estimasi optimal dan kontrol optimal (LQG) untuk sistem seperti UDP tanpa observasi hilang. Untuk fokus pada sifat dampak sinyal pengakuan, peneliti menganggap sistem seperti UDP tidak observasi hilang. Hal ini menunjukkan bahwa estimator optimal terdiri dari eksponensial. Dengan meningkatnya syarat, tidak ada persamaan riccati untuk menganalisis estimasi error kovarians, dan perhitungannya membutuhkan peningkatan waktu dan memori komputer secara eksponensial. Secara umum, ini cukup sulit dan terkadang tidak mungkin didapat solusi untuk masalah LQG. Alasannya berbeda dari alasan yang diketahui kesulitan untuk mendapatkan kontrol LMMSEestimator berbasis LQG. Pada penelitian disusun sebagai berikut: pengaturan dan masalah sistem dirumuskan. Untuk estimator optimal untuk sistem seperti UDP diturunkan. Berdasarkan estimator optimal, masalah LQG untuk sistem UDP untuk persamaan numerik disajikan untuk menggambarkan hasil utama penelitian.

\section{Standar Estimasi}

Pada bagian ini, dengan sebuah numerik, peneliti menunjukkan hasil estimasi dan efisiensi komputasi dari estimator optimal untuk C/A (ACK) dan Kasus C/A (NACK) (seperti kasus mirip TCP dan UDP). Pertimbangkan yang tidak stabil sistem di dengan parameter berikut:

$$
A=\left[\begin{array}{cccc}
1.001 & 0.005 & 0 & 0 \\
0.350 & 1.001 & -0.135 & 0 \\
-0.001 & 0 & 1.001 & 0.005 \\
-0.375 & -0.001 & 0.590 & 1.001
\end{array}\right]
$$

$\mathrm{R}=\operatorname{diag}(0.001,0.001), \mathrm{Q}=\mathrm{qq}$ ' dimana $\mathrm{q}=[0.003,1,-$ $0.005,-2.150]$ ' $, \mathrm{W}=\operatorname{diag}(1,0,0,0), \Lambda=2$.Peneliti memilih input kontrol yang dibatasi dengan tingkat packet loss $-v=0,2$ di C/A saluran, dan kesatuan estimasi serta kovarian kesalahan.

\section{Persamaan Numerik}

Dengan perhitungan eksponensial yang eksponensial, estimasi optimal, dibutuhkan sepenelitir 15 menit untuk menjalankan simulasi dengan langkah waktu di desktop umum komputer dengan frekuensi CPU $2 \mathrm{GHz}$ dan memori 8 GB. 

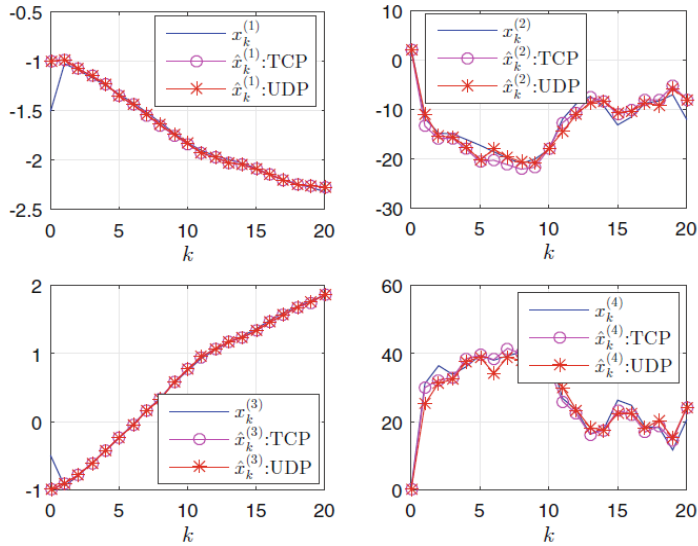

Gambar 3. Status sistem dan perkiraannya adalah komponen dari keadaan sistem sebenarnya. " TCP" dan "UDP" adalah estimasi optimal untuk sistem seperti TCP dan UDP.

Dimana $\mathrm{xk} \in \mathrm{Rn}$ adalah keadaan sistem, uk $\in \mathrm{Rq}$ masukan kontrol, dan yk $\in$ Rp pengamatan $\omega \mathrm{k}$ dan $v \mathrm{k}$ adalah nol berarti suara Gaussian dengan kovarians $Q \geq$ 0 dan $\mathrm{R}>0$, masing-masing. $v \mathrm{k}$ adalah i.i.d. Urutan acak Bernoulli dengan mean $v$ untuk menggambarkan packet loss pada kanal controllers-to-actuators (C/A). Artinya, $v \mathrm{k}=1$ menunjukkan bahwa paket kontrol uk telah berhasil dikirim ke aktuator, jika tidak $v \mathrm{k}=0$. Kondisi awal $\mathrm{x} 0$ diasumsikan Gaussian dengan mean ${ }^{-} \mathrm{x} 0$ dan kovarians P0. Selain itu, $\mathrm{x} 0, v \mathrm{k}, \omega \mathrm{k}$, dan vk saling independen. A, B, C, Q, dan $\mathrm{R}$ adalah matriks dengan dimensi yang kompatibel.

Untuk kesederhanaan nosional, kami menggunakan "kasus S/E" untuk menunjukkan kasus bahwa paket kerugian terjadi pada saluran sensor-ke-estimator $(\mathrm{S} / \mathrm{E})$, dan "kasus C/A (ACK)" untuk menunjukkan kasus yang mengendalikan paket dijatuhkan dengan ACK, dan "kasus S/E + C/A (ACK)".

Untuk menunjukkan keduanya gagasan serupa berlaku untuk tidak ada pengakuan (NACK), dan terkait skenario dapat didefinisikan di jalan yang sama. Sistem yang dijelaskan di tanpa cadangan dilambangkan dengan SN, dan yang satu dengan fastis dilambangkan dengan SA. Masalah estimasi untuk kasus S/E telah dibahas di . Disini peneliti fokus pada perkiraan optimal dan masalah kontrol untuk kasus C/A (NACK). Dengan demikian peneliti asumsikan saluran $\mathrm{S} / \mathrm{E}$ tersebut bebas dari packet loss.

$$
\begin{aligned}
x_{k+1} & =A x_{k}+\nu_{k} B u_{k}+\omega_{k} \\
y_{k} & =C x_{k}+v_{k},
\end{aligned}
$$

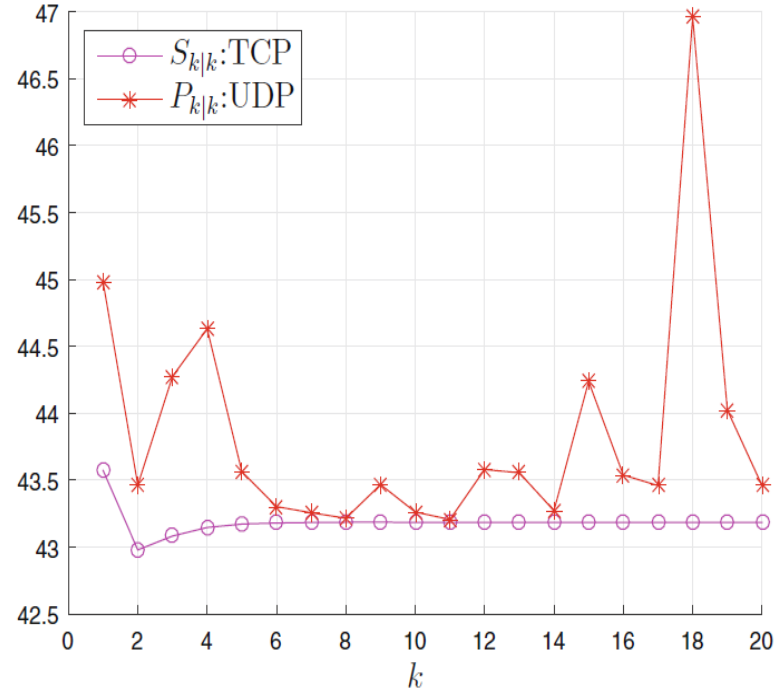

Gambar 4. Sistem menyatakan dan perkiraannya. Sk|k dan Pk|k adalah kovarian kesalahan estimasi untuk sistem seperti TCP dan UDP

\subsection{Menjalankan waktu dari estimator optimal untuk sistem TCP \\ Untuk kasus C/A (NACK), fungsi kepadatan} probabilitas dari keadaan sistem adalah campuran Gaussian. Pengukur optimal terdiri dari istilah yang meningkat secara eksponensial dan perhitungannya memakan waktu. Tidak ada persamaan seperti Riccati yang tersedia menganalisis kinerjanya. Karena kompleksitas estimator optimal, cukup sulit dan terkadang tidak mungkin untuk mendapatkan kontrol LQG yang optimal. Hasil ini menunjukkan bahwa perkiraan masalah untuk kasus C/A (NACK) berbeda jauh dari itu kasus S/E dalam banyak aspek termasuk pdf keadaan sistem, estimator optimal, Persamaan Riccati, kondisi stabilitas, dan sebagainya. Perbandingan perbedaan untuk menganalisa stabilitas estimator optimal, sebuah auxiliary metode estimator dikembangkan pada penelitian berikutnya. Penelitian lebih lanjut sensor pintar memiliki tingkat aplikasi yang luas di banyak bidang, dan skema pemicu event atau pemicu encoder telah diusulkan untuk sensor cerdas guna memperbaiki estimasi kesatuan untuk sistem yang tunduk pada berbagai kendala komunikasi . Jika aktuator dan sensor memiliki beberapa kemampuan komputasi, bukankah itu mungkin untuk merancang sebuah encoder, yang dapat mengkodekan semua informasi ACK ke dalam sebuah data paket dengan panjang yang terbatas, atau pemicu acara untuk sinyal pengakuan mengurangi kompleksitas perhitungan estimator optimal. 


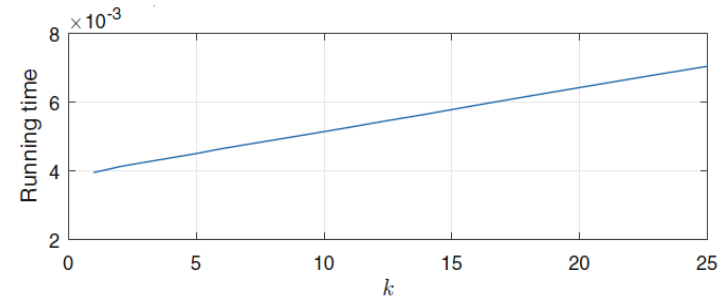

Gambar 5. Menjalankan waktu dari estimator optimal untuk sistem mirip TCP

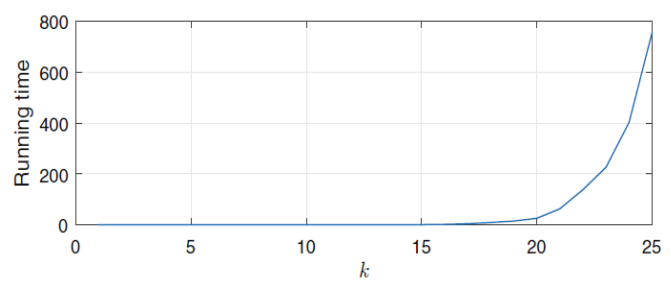

Gambar 6. Menjalankan waktu dari estimator optimal untuk sistem UDP

\subsection{Metode Estimasi Tambahan}

Untuk sistem seperti UDP tanpa observasi hilang, karena kompleksitas koefisien, tidak ada rumus rekursif untuk menghitung estimasi. Dengan demikian metode persamaan riccati tidak dapat digunakan untuk menganalisis kovarian kesalahan. Selain itu, bagian penjumlahan dalam $\mathrm{Pk} \mid \mathrm{k}$ mengandung istilah yang meningkat secara eksponensial, yang tidak hanya menghasilkan persyaratan komputasi yang sangat tinggi pada memori dan waktu CPU, namun juga membawa kesulitan dalam menentukan stabilitas Kk|k. Dalam penelitian ini, mengembangkan metode estimator tambahan untuk mempelajari kestabilan $\mathrm{Pk} \mid \mathrm{k}$.

Pengaturan Sistem

$$
\begin{aligned}
x_{k+1} & =A x_{k}+\nu_{k} B u_{k}+\omega_{k} \\
y_{k} & =C x_{k}+v_{k}
\end{aligned}
$$

Dimana parameternya sama dengan NCS seperti UDP tugas utama penelitian ini adalah mengatasi masalah sebagai berikut: Bangun urutan variabel acak, yang disebut sistem pelengkap menyatakan, sehingga estimasi mereka dapat dihitung secara rekursif, dan kovarian kesalahannya dapat dibandingkan dengan estimator optimal.

Beberapa pendahuluan dikumpulkan sebagai berikut. Misalkan $\mathrm{X}$ dan $\mathrm{Y}$ adalah dua variabel acak, dan misalkan $\mathrm{f}(\mathrm{X}, \mathrm{Y})$ menjadi fungsi dari dua variabel acak ini variabel acak kemudian sifat berikut tahan .

$$
\begin{aligned}
\operatorname{cov}(X) & =\mathbb{E}\left[X^{2}\right]-(\mathbb{E}[X])^{2} \\
\mathbb{E}_{X, Y}[f(X, Y)] & =\mathbb{E}_{X}\left[\mathbb{E}_{Y}[f(X, Y) \mid X]\right] \\
\operatorname{cov}(X) & =\mathbb{E}[\operatorname{cov}(X \mid Y)]+\operatorname{cov}(\mathbb{E}[X \mid Y]) .
\end{aligned}
$$

Numerik pada bagian ini, dengan sebuah numerik, kami memverifikasi hasil utama dari penelitian ini, Artinya, hubungan yang terjalin dalam teorema. Perhatikan tiga sistem dengan dimensi yang berbeda yang pertama, dilambangkan dengan $\mathrm{S} 1$, ini sistem yang digunakan di yang kedua, dilambangkan dengan S2, adalah sistem dengan berikut parameternya:

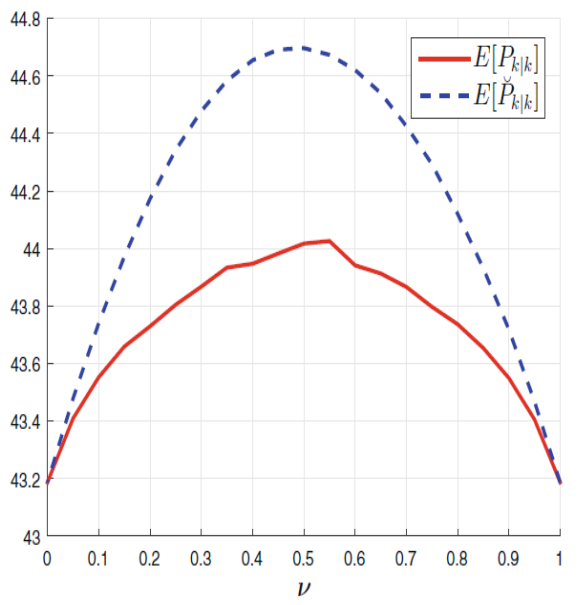

Gambar 7. Hubungan antara E [Pk|k] dan E [Pk|k] untuk sistem S1 Jejak kovarian error yang diharapkan

$$
A=\left[\begin{array}{cc}
1.141 & 0 \\
0 & 0.5
\end{array}\right], B=\left[\begin{array}{c}
-1 \\
1
\end{array}\right], C=\left[\begin{array}{ll}
-1 & 1
\end{array}\right], Q=\left[\begin{array}{cc}
20 & 0 \\
0 & 20
\end{array}\right], R=20
$$

dan yang ketiga, dilambangkan dengan S3, adalah sistem dengan parameter sebagai berikut:

$$
A=\left[\begin{array}{ccc}
1.1 & 1 & 0 \\
0 & 1.25 & 0 \\
1 & 1 & 0.5
\end{array}\right], B=\left[\begin{array}{c}
-1 \\
1 \\
0
\end{array}\right], C=\left[\begin{array}{lll}
1 & 0 & 0 \\
0 & 1 & 0
\end{array}\right], Q=I_{3 \times 3}, R=I_{2 \times 2}
$$

Gambar 4, 5, dan 6 menunjukkan bahwa untuk sistem yang berbeda, ${ }^{\smile} \mathrm{Pk} \mid \mathrm{k}$ lebih besar dari $\mathrm{Pk} \mid \mathrm{k}$ dalam arti rata-rata, yang memverifikasi teorema.

Tugas utama metode estimator tambahan sebenarnya adalah membangun acak proses $\{\breve{x k \mid I k\}}$, yang bisa juga dipandang sebagai proses pendamping dengan random proses $\{x k \mid I k\}$. Kovarian error dari $\{$ xk|Ik\} dapat dihitung dan berada di atas batas untuk $\{x k \mid I k\}$, memfasilitasi analisis Pk|k. Berdasarkan tambahan ini, metode estimator, kestabilan estimator optimal dipelajari pada penelitian berikut, dan dua estimator suboptimal yang efisien secara komputasi dikembangkan di penelitian berikutnya. 


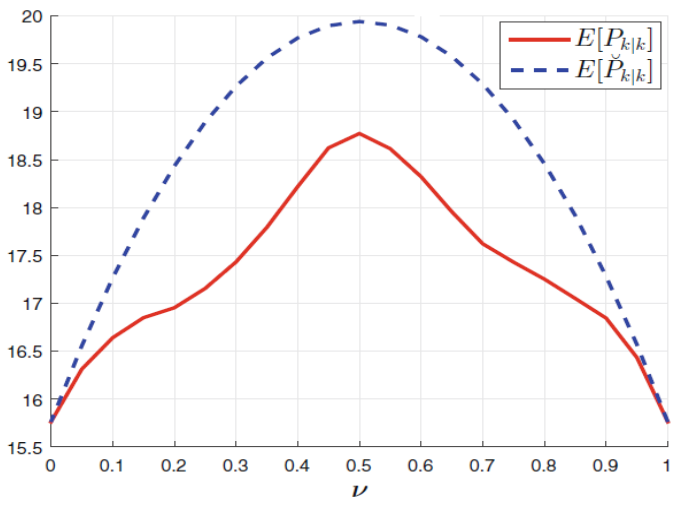

Gambar 8. Hubungan antara E [Pk | k] dan E [־Pk | k] untuk sistem S2 (Jejak kovarian error yang diharapkan)

\subsection{Keseimbangan Estimasi untuk Sistem UDP}

Dalam penelitian ini, mempelajari kestabilan estimator optimal untuk kasus C/A (NACK) Artinya, sistem seperti UDP tanpa observasi hilang. Dengan estimator tambahan metode, kondisi yang diperlukan dan memadai untuk stabilitas estimasi rata-rata matriks kovariansi kesalahan ditetapkan. Hal ini menunjukkan bahwa stabilitas tidak tergantung pada tingkat kehilangan paket kontrol, dan tidak terpengaruh oleh kurangnya pengakuan. numerik dan simulasi digunakan untuk menggambarkan hasil teoritis. Pengaturan sistem dan masalah dirumuskan kondisi yang diperlukan dan memadai untuk kestabilan estimator optimal diberikan numeriknya adalah disajikan untuk menggambarkan hasil utama .

Pengaturan Sistem sistem jaringan UDP seperti tanpa observasi hilang,

$$
\begin{aligned}
x_{k+1} & =A x_{k}+\nu_{k} B u_{k}+\omega_{k} \\
y_{k} & =C x_{k}+v_{k}
\end{aligned}
$$

Dimana parameternya sama dengan NCS seperti UDP, seperti ditunjukkan pada ketika kehilangan paket terjadi pada saluran sensor-ke-estimator, persamaan riccati yang dihasilkan mengandung variabel acak yang memodelkan paket kerugian.

Kemudian harapan kesalahan kovarians $\mathrm{Pk} / \mathrm{k}$ diadopsi untuk mengevaluasi kinerjanya kinerja. Demikian juga, untuk kasus C/A (NACK), Pk|k melibatkan variabel acak, juga, yang tidak $v \mathrm{k}$, tapi pengamatan Ik.

Karena itu kinerjanya dari estimasi dianalisis melalui ekspektasi Pk|k terhadap Ik. Bahwa E [Pk|k] tidak harus konvergen bahkan ketika uk mengambil fixed nilai. Untuk sistem tanpa ACK, kasus yang lebih kompleks, masuk akal untuk dipertimbangkan bahwa $\mathrm{E}[\mathrm{Pk} \mid \mathrm{k}]$ tidak harus konvergen baik. Oleh karena itu, kami prihatin dengan stabilitas (yaitu, boundedness), bukan konvergensi, dari E $[\mathrm{Pk} \mid \mathrm{k}]$. Kestabilannya Estimasi kesalahan kovariansi dalam arti mean didefinisikan sebagai berikut: Estimasi kesalahan rata-rata kovariansi EIk [Pk|k] dikatakan stabil, jika $\sup _{\mathrm{k}}$ EIk $[\mathrm{Pk} \mid \mathrm{k}]<\infty$, yaitu ada matriks pasti positif $\mathrm{P}$ tersebut bahwa EIk $[\mathrm{Pk} \mid \mathrm{k}] \leq \mathrm{P}$ untuk semua k. Tujuan utama penelitian ini adalah untuk memecahkan masalah kestabilan estimator optimal untuk sistem seperti UDP dan analisis dampak tingkat kehilangan paket kontrol pada stabilitas dan kinerja estimator optimal.

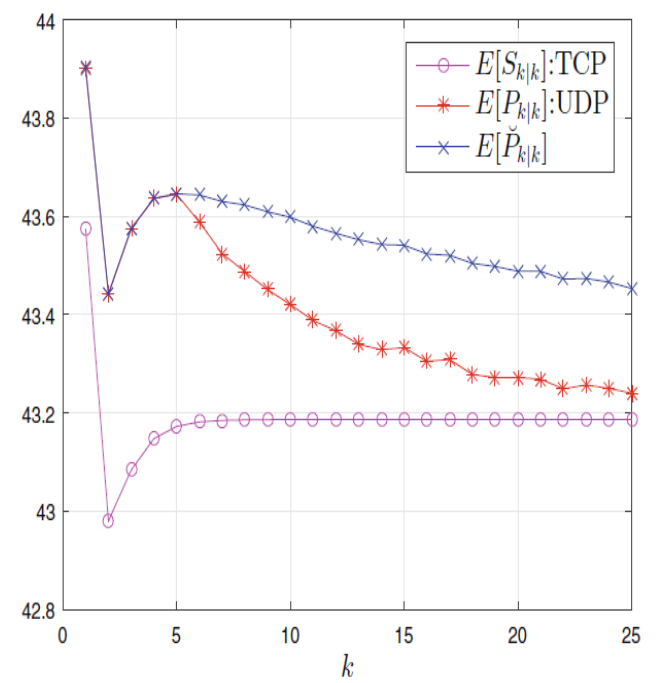

Gambar 9. Jejak kovarian, kotak input terbatas

$$
A=\left[\begin{array}{cc}
\sigma & 0 \\
0 & 0.5
\end{array}\right], \sigma=1.118, B=\left[\begin{array}{c}
-1 \\
1
\end{array}\right], C=\left[\begin{array}{ll}
-1 & 1
\end{array}\right], Q=\left[\begin{array}{cc}
20 & 0 \\
0 & 20
\end{array}\right] R=20 .
$$

\subsection{Uji Konvergensi}

Numerik pada bagian ini, dengan persamaan numerik, memverifikasi kestabilan estimator optimal dan menunjukkan dampak kerugian paket. Pertimbangkan sistem dengan parameter berikut,

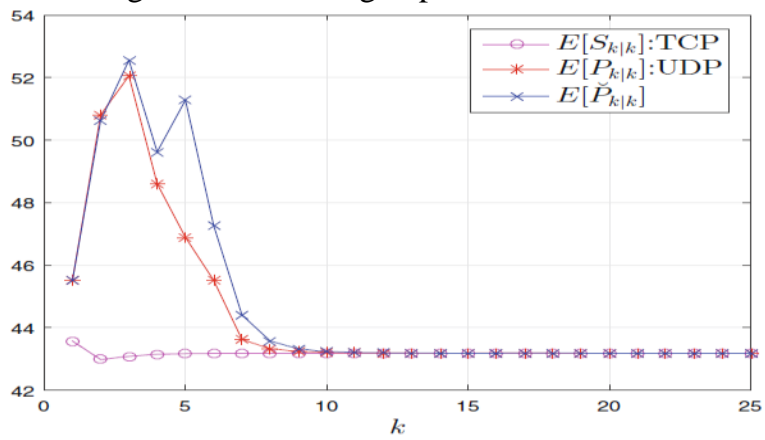

Gambar 10. Stabilitas kovarian kesalahan 

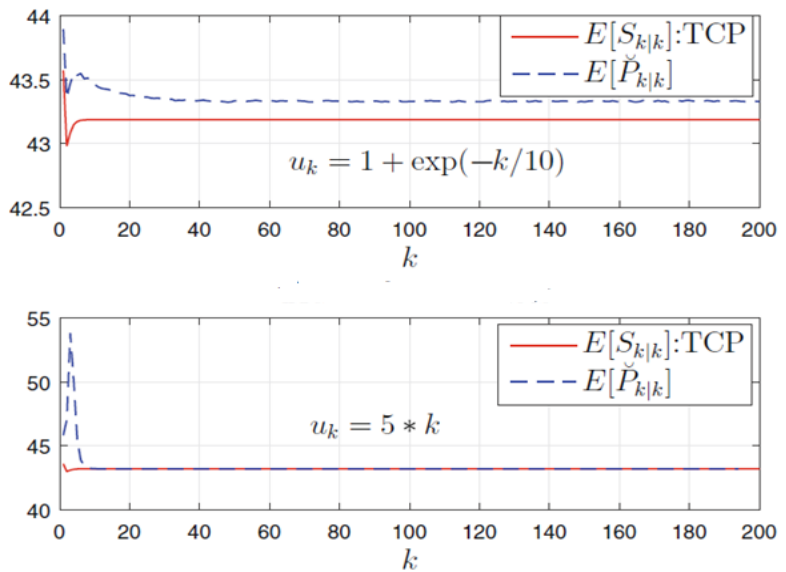

Gambar 11. Rata-rata jejak kovarians Sk | k dan ${ }^{`} \mathbf{P k}$ | $k$ untuk kedua kasus masukan yang dibatasi dan tidak terbatas.

Pada gambar 10, diverifikasi bahwa Sk $\mid \mathrm{k} \leq \mathrm{E}[\mathrm{Pk} \mid \mathrm{k}] \leq$ $\mathrm{E}\left[{ }^{\sim} \mathrm{Pk} \mid \mathrm{k}\right]$ dan $\mathrm{E}[\mathrm{Pk} \mid \mathrm{k}]$ dibatasi

untuk input yang terbatas dan tak terbatas, yang dinyatakan dalam theorems 10 masing-masing. Dengan memperhatikan kompleksitas komputasional, langkah simulasi pada gambar 10 adalah 25. Pada gambar 11, kami menunjukkan stabilitas $\mathrm{E}\left[{ }^{\sim} \mathrm{Pk} \mid \mathrm{k}\right]$ dengan langkah simulasi 200. Dengan menggabungkan dengan hasil E $[\mathrm{Pk} \mid \mathrm{k}] \leq \mathrm{E}\left[{ }^{\circ} \mathrm{Pk} \mid \mathrm{k}\right]$, disarankan agar E [Pk $\left.\mid \mathrm{k}\right]$ stabil. Dengan memperbaiki urutan input dan mengubah tingkat kehilangan paket dari 0 menjadi 1 , rata-rata jejak kovarian kesalahan di bawah tingkat kehilangan paket yang berbeda adalah di ilustrasikan pada gambar 12. Ini menunjukkan bahwa rata-rata jejak kovarian kesalahan meningkat seiring dengan tingkat paket hilang, mencapai maksimum mendekati 0,5 , kemudian turun sebagai tingkat kehilangan paket meningkat dari 0,5 menjadi 1 . Kestabilan mean error covariance adalah lagi diverifikasi, dan dampak paket hilang pada estimasi disajikan. Bisa juga . Dijelaskan dalam tampilan entropi bahwa semakin tidak pasti keacakan paket Kerugiannya, semakin buruk kinerja estimator menjadi. Pada gambar 12, peneliti dapat melihat bahwa stabilitas tidak tergantung pada tingkat packet loss, dan hilangnya ACK tidak mempengaruhi stabilitas $\mathrm{E}[\mathrm{Pk} \mid \mathrm{k}]$,

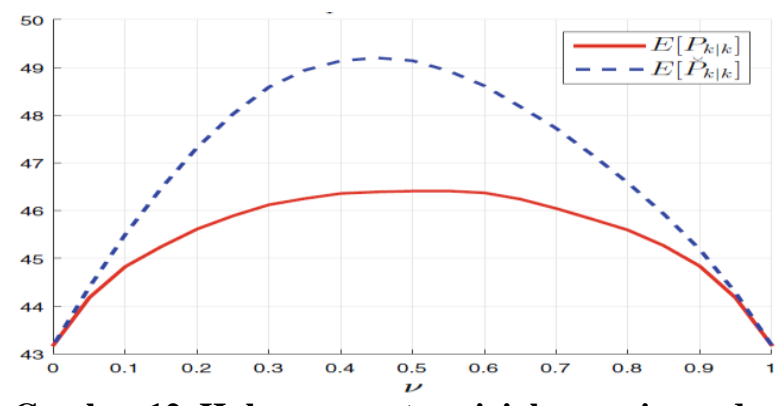

Gambar 12. Hubungan antara jejak covariance dan paket yang hilang
Dalam penelitian ini, peneliti telah mempelajari masalah estimasi optimal untuk C/A (NACK) kasus. Telah ditunjukkan bahwa untuk sistem tanpa ACK pdf dari sistem keadaan adalah campuran gaussian dengan istilah eksponensial meningkat dan perhitungan perkiraan optimal memakan waktu. Dengan metode estimator tambahan, peneliti telah menetapkan kondisi yang diperlukan dan cukup untuk stabilitas mean estimasi error covariance, dan telah mengungkapkan hubungan antara stabilitas dan tingkat kehilangan paket kontrol.

Ada dua kemungkinan ekstensi. Salah satunya adalah untuk memperpanjang ke estimasi optimal untuk kotak $\mathrm{S} / \mathrm{E}+\mathrm{C} / \mathrm{A}$ (NACK). Untuk kasus S/E (yaitu, sistem mirip TCP) dengan $\sigma=1,0541,1,1180$, dan 1,4142 , nilai kritis masing-masing adalah $0,1,0,2$, dan 0,5 . Stabilitas $\mathrm{E}[\mathrm{Pk} \mid \mathrm{k}]$ untuk kasus S/E + C/A (NACK) dengan $\sigma=$ 1,0541, 1,1180, dan 1.4142 ditunjukkan pada gambar 13 . Tampaknya ada nilai kritis untuk stabilitas dari estimator, mirip dengan kasus S/E, dan nilai kritisnya terlihat sama seperti itu untuk kasus S/E. Arah penelitian lainnya adalah mempelajari konvergensi $\mathrm{E}[\mathrm{Pk} \mid \mathrm{k}]$ untuk $\mathrm{S} / \mathrm{E}+\mathrm{C} / \mathrm{A}$ (NACK). Meskipun E $[\mathrm{Pk} \mid \mathrm{k}]$ sendiri tidak konvergen, gambar 14 menunjukkan bahwa ketika input kontrol cenderung nol, artinya, limk $\rightarrow \infty$ uk $=0$, E $[\mathrm{Pk} \mid \mathrm{k}]$ untuk S/E + C/A (NACK) konvergen untuk itu untuk kasus $\mathrm{S} / \mathrm{E}+\mathrm{C} / \mathrm{A}(\mathrm{ACK})$
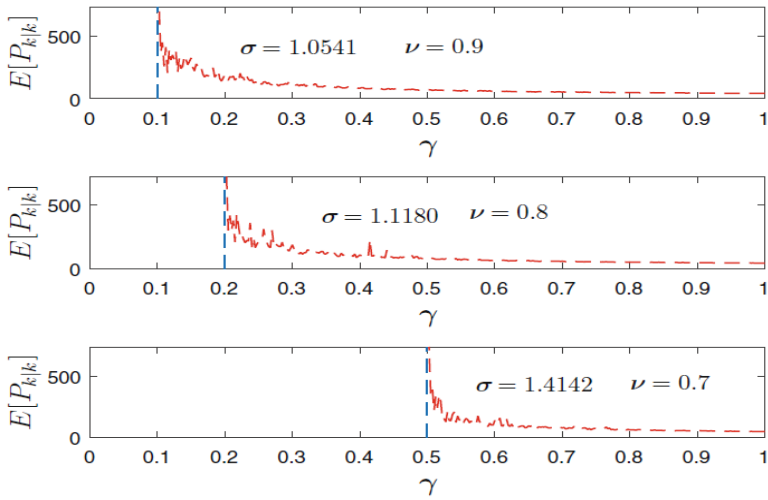

Gambar 13. Hubungan antara jejak covariance dan paket hilang 


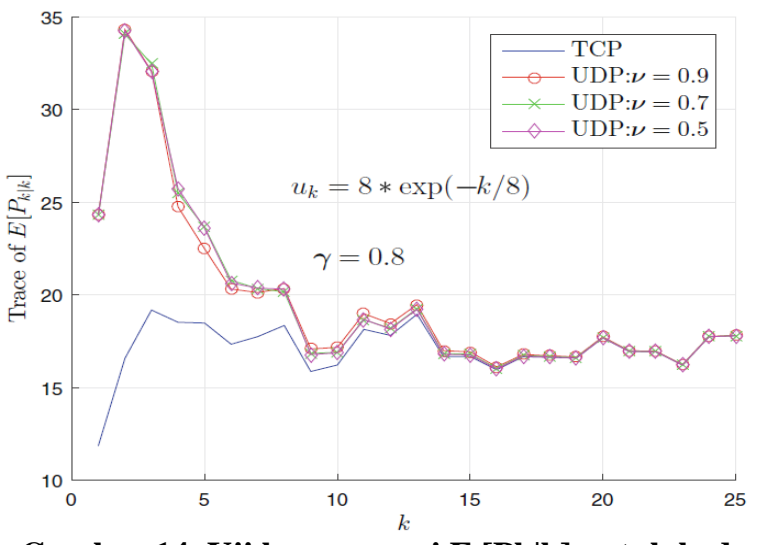

Gambar 14. Uji konvergensi E [Pk|k] untuk kedua kasus masukan yang dibatasi dan tidak terbatas.

\subsection{Estimator Tambahan Sistem UDP}

Dalam penelitian ini, peneliti mengembangkan dua estimator suboptimal untuk sistem seperti UDP tanpa observasi hilang. Estimator suboptimal pertama, disebut algoritma penyaringan cepat 1 (FF1), dikembangkan sesuai dengan gagasan metode estimator tambahan. Ini adalah estimator linier dan dapat dihitung secara rekursif. Kedua estimator sub optimal, yang disebut algoritma penyaringan cepat 2 (FF2), dirancang sedikit memodifikasi estimator tambahan yang diusulkan Dibandingkan dengan FF1, itu adalah a estimator nonlinier dan mampu menahan degradasi kinerja yang disebabkan oleh besar masukan kontrol pengaturan sistem adalah diperkenalkan. Dua estimator suboptimal dikembangkan dalam numerik disajikan untuk menggambarkan hasil utama.

Pengaturan sistem jaringan UDP seperti tanpa observasi hilang,

$$
\begin{aligned}
x_{k+1} & =A x_{k}+\nu_{k} B u_{k}+\omega_{k} \\
y_{k} & =C x_{k}+v_{k}
\end{aligned}
$$

dimana parameternya sama dengan NCS seperti UDP

Dibandingkan dengan $\mathrm{xk}$, estimator $\sim \mathrm{xk}$ masih mengandung istilah eksponensial, namun ada rumus rekursif untuk mereka sebagai berikut, yang memungkinkan estimator menjadi dihitung secara rekursif dan menghindari perhitungan yang meningkat secara eksponensial. Untuk sistem pada (6), algoritma penyaringan cepat 1 (FF1) diformulasikan sebagai satu set kalman-penyaringan seperti persamaan sebagai berikut:

$$
\begin{aligned}
\tilde{x}_{k+1 \mid k} & =A \tilde{x}_{k \mid k}+\nu B u_{k} \\
\tilde{P}_{k+1 \mid k} & =A \tilde{P}_{k \mid k} A^{\prime}+U_{k}+Q \\
\tilde{x}_{k+1 \mid k+1} & =\tilde{x}_{k+1 \mid k}+K_{k+1}\left(y_{k+1}-C \tilde{x}_{k+1 \mid k}\right) \\
\tilde{P}_{k+1 \mid k+1} & =\left(I-K_{k+1} C\right) \tilde{P}_{k+1 \mid k}\left(I-K_{k+1} C\right)^{\prime}+K_{k+1} R K_{k+1}^{\prime}
\end{aligned}
$$

Persamaan di atas dapat diperoleh dari beberapa perhitungan aljabar.

Sebagai estimator linier, kinerja FF1 lebih rendah dari linear estimator minimum mean square error (LMMSE), karena estimator LMMSE adalah dikenal sebagai yang optimal diantara semua estimator linier. Alasan untuk mengenalkan FF1 adalah alat ini mungkin merupakan alat potensial untuk menganalisa kestabilan yang optimal estimator untuk sistem seperti UDP dengan kedua input kontrol dan pengamatan hilang. PDFs $\sim \mathrm{xk}$ berbeda dari xk hanya di (6). Ini adalah perbedaan aminor seperti itu yang membawa bentuk rekursif (15) dan (15) untuk $\sim$ xk dan $\sim$ Pk. Persamaan di (15) nampak sama dengan estimator untuk. Kasus seperti UDP di [1]. Sebenarnya mereka sangat berbeda. Dalam mungkin menganggap pdf dari $\mathrm{p}(\mathrm{xk}+1 \mid \mathrm{Ik})$ adalah Gaussian, maka estimator diperoleh dengan filter Kalman. $\mathrm{Kk}+1$ adalah dihitung oleh $\mathrm{Pk}+1 \mid \mathrm{k}$, dan $\mathrm{Pk}+1 \mid \mathrm{k}$ berevolusi dalam persamaan Riccati. Dalam bab ini, berasal dari keadaan sistem pelengkap $\sim$ xk oleh filter jumlah Gaussian, dan pdf dari $\mathrm{p}(\sim \mathrm{xk} \mid \mathrm{Ik})$ dan $\mathrm{p}(\sim \mathrm{xk}+1 \mid \mathrm{Ik})$ adalah campuran Gaussian. Selain itu, pada (15), Kk +1 dihitung via $\mathrm{Sk}+1 \mid \mathrm{k}$, bukan oleh $\mathrm{Kk}+1=\sim \mathrm{Pk}+1 \mid$ $\mathrm{kC} \mid(\mathrm{C} \sim \mathrm{Pk}+1|\mathrm{kC}|+\mathrm{R})-1$. Jadi dengan mengganti (15) rumus yang diperoleh bukanlah persamaan riccati standar.

Seperti yang ditunjukkan sebelumnya, perhitungan estimasi optimal memakan waktu. Secara umum, stabilitas algoritma penyaringan suboptimal yang disebutkan di atas adalah

tidak pasti maka pada bagian ini, kami menunjukkan bahwa dalam beberapa kondisi yang diusulkan FF1 stabil. Sebelum mempresentasikan hasil ini, Dimana L = $\mathrm{C}$ A, dan tentukan $\Phi \mathrm{k}$ i, untuk $0 \leq \mathrm{i} \leq \mathrm{k}$

$$
\begin{aligned}
& \Phi_{i}^{k} \triangleq\left(\prod_{j=i+1}^{k}\left(A-K_{j+1} L\right)\right)\left(I-K_{i+1} C\right), \text { for } i<k \\
& \Phi_{k}^{k} \triangleq\left(I-K_{k+1} C\right), \text { for } i=k,
\end{aligned}
$$

Persamaan dalam (8) menyediakan algoritma penyaringan untuk sistem dengan tak terbatas masukan kontrol Namun, $\lambda 1 \mathrm{kin}(8)$ dihitung melalui $\psi 0 \mathrm{k}$ dan $\psi 1$ $\mathrm{k}$, yang masih membutuhkan memori dan waktu yang meningkat secara eksponensial. Untuk mengatasi masalah ini, peneliti mengadopsi sebuah aproksimasi, biasanya digunakan di GPB dan IMM, dengan mengasumsikan $\mathrm{p}\left(\ulcorner\mathrm{xk} \mid \mathrm{Ik}) \approx \mathrm{N}^{\smile} \mathrm{xk}\left(\left\ulcorner\mathrm{xk}\left|\mathrm{k},{ }^{\smile} \mathrm{Pk}\right| \mathrm{k}\right)\right.\right.$. Dengan pendekatan ini, 


$$
\begin{aligned}
& \psi_{k}^{0}=p\left(y_{k+1} \mid r_{k}=0\right) \approx \mathcal{N}_{y_{k+1}}\left(C A \breve{x}_{k \mid k}, \breve{P}_{k+1}^{Y}\right) \\
& \psi_{k}^{1}=p\left(y_{k+1} \mid r_{k}=1\right) \approx \mathcal{N}_{y_{k+1}}\left(C A \breve{x}_{k \mid k}+C B u_{k}, \breve{P}_{k+1}^{Y}\right)
\end{aligned}
$$

Pada bagian ini membandingkan algoritma penyaringan cepat dengan optimal dan verifikasi batasan kovarian error. Pertimbangkan sistemnya dengan parameter sebagai berikut
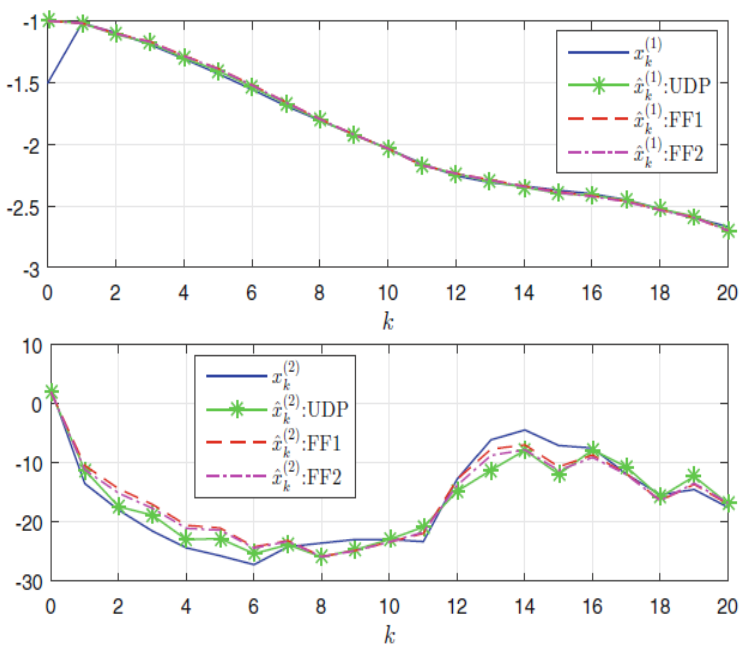

Gambar 15. Status sistem dan perkiraan keadaan

$$
\begin{gathered}
A=\left[\begin{array}{cccc}
1.001 & 0.005 & 0 & 0 \\
0.350 & 1.001 & -0.135 & 0 \\
-0.001 & 0 & 1.001 & 0.005 \\
-0.375 & -0.001 & 0.590 & 1.001
\end{array}\right] \\
B=\left[\begin{array}{l}
0.001 \\
0.540 \\
-0.002 \\
-1.066
\end{array}\right] C=\left[\begin{array}{llll}
1 & 0 & 0 & 0 \\
0 & 0 & 1 & 0
\end{array}\right]
\end{gathered}
$$

$\mathrm{R}=\operatorname{diag}(0.001,0.001), \mathrm{Q}=\mathrm{qq}$ ' dimana $\mathrm{q}=[0.003$, $1,-0.005,-2.150]$ ' $, \mathrm{W}=\operatorname{diag}(1,0,0,0), \Lambda=2$. Pertama, kinerja penyaringan cepat dan optimal dibandingkan. Dengan memilih input kontrol yang dibatasi dengan tingkat kehilangan paket 0,2 di saluran $\mathrm{C} / \mathrm{A}$, dan gunakan jejak kovarians untuk mengevaluasi kinerjanya. Berdasar pada eksponensial dengan meningkatkan perhitungan penyaringan yang optimal, kami menjalankan simulasi untuk 20 langkah.

Status sistem dan perkiraannya ditunjukkan pada gambar. 15 dan 16. Akal akar square error (RMSE) digunakan untuk mengevaluasi kinerja estimasi FF1 dan FF2, dan hasilnya disajikan pada gambar 17 , dari mana peneliti dapat melihat bahwa untuk pengendalian terbatas
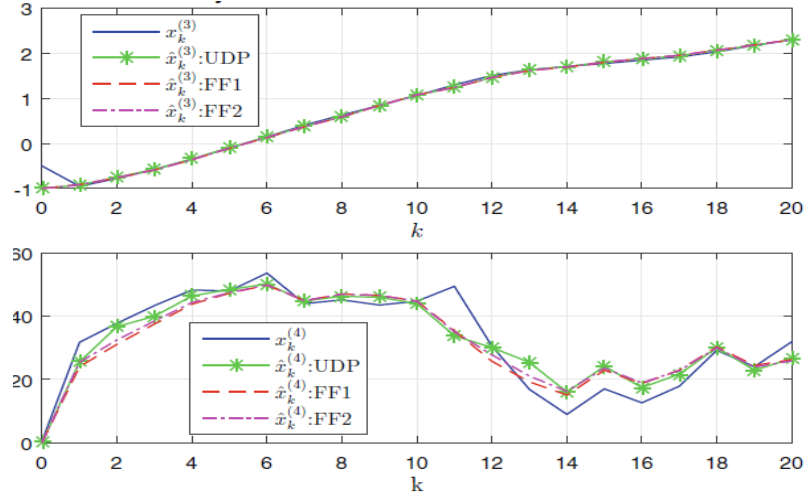

Gambar 16. Status sistem dan perkiraan keadaan

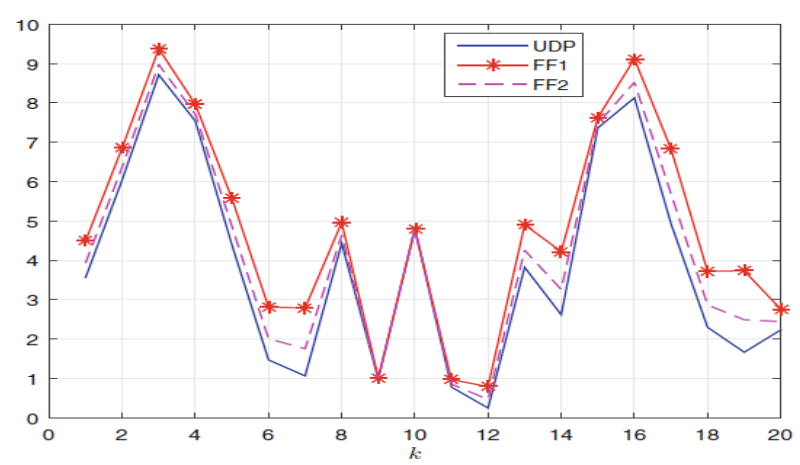

Gambar 17. Akar persegi error untuk estimator optimal, FF1, dan FF2
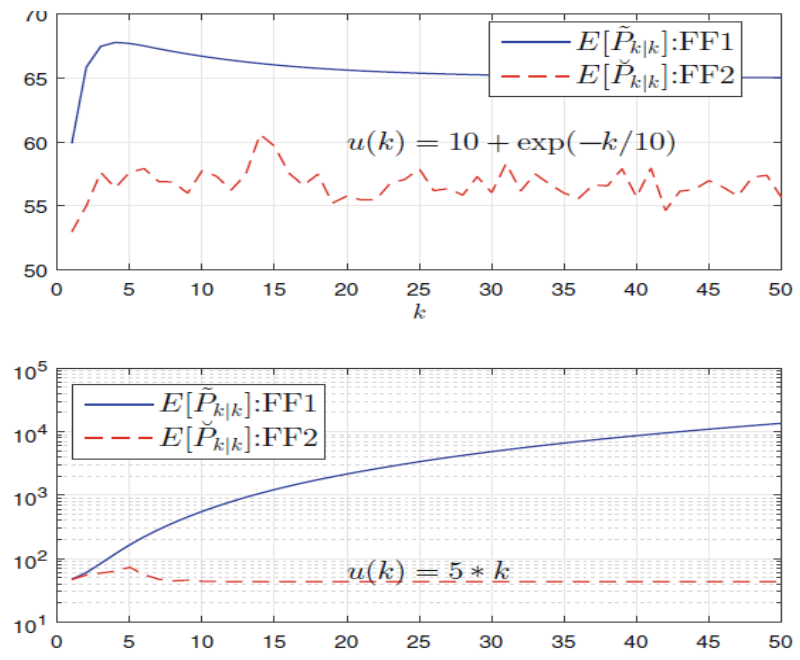

Gambar 18. Rata-rata estimasi error kovariansi untuk FF1 dan FF2

Input dengan skala kecil, perkiraan kinerja FF1 dan FF2 sudah dekat dan inferior bit kecil ke estimator optimal.

Untuk sistem dengan input kontrol yang dibatasi, perkiraan kesalahan kovariansi FF1 dan FF2 di ilustrasikan pada gambar 18, dan stabil seperti yang dinyatakan dalam teorema 8 dan 9. Untuk sistem dengan input kontrol yang besar, hasil simulasi menunjukkan bahwa FF2, seperti estimator optimal, juga dapat menahan degradasi kinerja estimasi, Dalam penelitian 
ini, telah mengembangkan dua algoritma penyaringan cepat untuk memperbaiki komputasi efisiensi, dan mengingat kondisi stabilitas mereka. Untuk kasus dimana minor degradasi kinerja estimasi dapat ditoleransi, algoritma FF1 dan FF2 adalah cukup bagus bergantian.

Seperti sistem seperti UDP dapat dilihat sebagai kelas khusus sistem hibrida atau model markov yang tersembunyi, yang banyak digunakan di berbagai bidang, seperti pengenalan ucapan, pengenalan tulisan tangan, keuangan, gambar pengolahan, bioinformatika. Ada banyak metode estimasi untuk sistem ini, hanya untuk beberapa nama: filter pencampuran hipotesis, filter partikel, berinteraksi dengan beberapa model estimator, estimator maksimum, dan filter sensitif risiko. Sebuah penelitian potensial dan menarik adalah menerapkan metode estimasi negara ini dikembangkan untuk sistem markov atau hybrid ke sistem. Seseorang dapat memperluas FF1 dan FF2 ke sistem seperti UDP dengan kontrol dan pengamatan kerugian paket, dengan menggunakan $\mathrm{xk}+1|\mathrm{k}+1=\mathrm{A} x \mathrm{k}| \mathrm{k}+v \mathrm{Buk}$ dan $\mathrm{Pk}+1 \mid$ $\mathrm{k}+1=\mathrm{APk}|\mathrm{k} \mathrm{A}|+\mathrm{Q}+\mathrm{v}^{-} \mathrm{v}|\mathrm{k} \mathrm{b}|$. Bila pengamatan $\mathrm{yk}+$ 1 hilang. Sedangkan dalam kasus ini, analisisnya kinerja stabilitas dan estimasi FF1 dan FF2 menjadi lebih rumit dan kebutuhan belajar.

\section{KESIMPULAN}

Kesimpulan dalam teorema juga berlaku untuk sistem seperti UDP, karena sistem UDP-like benar-benar hilang. Jika beberapa kesalahan aproksimasi diijinkan, maka algoritma pemrograman dinamis adaptif akan menjadi teknik yang efektif untuk memecahkan masalah pengendalian optimal kira-kira. Sistem seperti UDP dapat dipandang sebagai sistem markov, dan pendekatan sistem theobotov membantu merancang estimator yang efisien secara komputasi dan robust. Mirip dengan LMQE-estimator berbasis LQG, secara umum, tidak ada solusi untuk masalah LQG yang dipertimbangkan, namun alasannya berbeda. Saat menyelesaikan masalah LQG berbasis LMMSE, uk muncul dalam penyebut keuntungan filter $\mathrm{Kk}+1$, yang membuat pengoptimalan nonlinier dan non-cembung. Akibatnya, sulit untuk mendapatkan solusinya. Namun, seperti yang ditunjukkan sebelumnya,. Sebenarnya, sebelum menyelesaikan masalah optimasi nonlinier, kesulitan pertama terletak pada kenyataan bahwa tidak ada ekspresi eksplisit untuk integral fungsi $(\varphi \varphi) / \varphi$ dengan fungsi eksponensial dalam pembilang dan penyebutnya.

\section{SARAN}

Dalam penelitian untuk sistem Quasi-TCP umum yang telah diusulkan secara optimal estimator dan diberi kesimpulan tentang solvabilitas pengendali LQG yang optimal. Juga pengontrol LQG suboptimal dirancang. Seperti diberikan untuk mendemonstrasikan potensi dan keefektifan pengontrol LQG yang diusulkan. Namun, penerapan metode yang diusulkan pada sistem real-time dapat menghadapi serangkaian kesulitan: tingkat kehilangan paket mungkin tidak diketahui, dan terkadang ada kendala pada besarnya input kontrol. Untuk mengatasi masalah ini, penelitian lebih lanjut difokuskan untuk memasukkan ke dalam metode yang kami gunakan sebagai algoritma estimasi adaptif untuk mengidentifikasi on-line tingkat kehilangan paket yang tidak diketahui dan teknik kontrol prediktif model untuk mengatasi kendala besarnya.

\section{DAFTAR PUSTAKA}

Digital Transmission Engineering, Second Edition John B. Anderson

Channel Equalization for Wireless Communications: From Concepts to Detailed Mathematics Gregory E. Bottomley

Digital Filters: Principle and Applications with MATLAB Fred J. Taylor

Frequency Stabilization: Introduction and Applications Venceslav F. Kroupa

Handbook of Position Location: Theory, Practice, and Advances Edited by Seyed (Reza) Zekavat and R. Michael Buehrer

Introduction to WLLs: Application and Deployment for Fixed and Broadband Services Raj Pandya Trellis and Turbo Coding Christian B. Schlegel and Lance C. Perez

Millimeter Wave Communication Systems Kao-Cheng Huang and Zhaocheng Wang

Mobile Ad Hoc Networking: Cutting Edge Directions, Second Edition Stefano Basagni, Marco Conti, Silvia Giordano, and Ivan Stojmenovic

Non-Gaussian Statistical Communication Theory David Middleton

Resource Allocation in Uplink OFDMA Wireless Systems: Optimal Solutionsand Practical Implementations Elias E. Yaacoub and Zaher Dawy

Techniques for Surviving the Mobile Data Explosion Dinesh Chandra Verma and Paridhi Verma

Theory of Code Division Multiple Access Communication Kamil Sh. Zigangirov

Wireless Broadband: Conflict and Convergence Vern Fotheringham and Shamla Chetan

Wireless Communications in the 2lst Century Mansoor Sharif, Shigeaki Ogose, and Takeshi Hattori

Wireless LAN Radios: System Definition to Transistor Design Arya Behzad

Wireless Video Communications: Second to Third Generation and Beyon Lajos Hanzo, Peter J. Cherriman, and Jurgen Streit 